\title{
Oncofertility: An Area of Reproductive Medicine Capable to Protect the Fertility of Cancer Patients
}

\author{
Ana Flávia Bezerra da Silva ${ }^{1 *}$, Thais Perez Leal', Amanda Torres Panta ${ }^{2}$ and Deborah de Melo \\ Magalhães Padilha ${ }^{2}$ \\ ${ }^{1}$ State University of Ceara, Ceara, Brazil \\ ${ }^{2}$ Potiguar University, Rio Grande do Norte, Brazil
}

*Corresponding author: Ana Flávia Bezerra da Silva, Bachelor of Biomedicine and Master of Veterinary Science, State University of Ceará, Ceara, Fortaleza - CE, 60741-000, Brazil

\begin{abstract}
Cancer, also called malignant neoplasm, is a disorder which can be manifested in almost anywhere in the body as a result of errors in the cell cycle control machinery, resulting in the formation of tumors. Although the pursuit of a cure is still a top priority for cancer research, the concern about the side effects that the treatment of the disease can produce is an important factor that must be taken into account. One undesirable consequence is infertility, since patients are subordinate to the cytotoxic dynamics of radio and chemotherapy. In this sense, assisted reproduction provides an alternative to protect the fertility of the bearer, through the use of reproductive biotechniques associated with gametes, tissues and embryo freezing, either by vitrification or conventional slow freezing. Cryopreservation is a reproductive biotechnique in which extremely low temperatures are used in order to decrease cellular metabolism. This technique has gained interest in the field of oncofertility, offering hope for men and women, cancer patients, granting them the possibility of being able to procreate biological children once their treatment for cancer is concluded. Although the cryopreservation technique allows the preservation of viability to diverse tissues and cells used during in-vitro fertilization (IVF) and artificial insemination ( $\mathrm{Al}$ ), among other techniques, the low temperatures from cryopreservation can lead to irreversible cellular damage. As a result, cryoprotectants appear to contribute to the reduction of the rate of deleterious effects caused by intracellular ice formation, increasing the survival rate of viable gametes. Therefore, in the present article a bibliographic survey was carried out from 1983 to 2018, through databases such as Scielo and Pubmed. Eighty-two articles were used as reference, having a requirement for inclusion of scientific articles published in Portuguese, English and Spanish, with the purpose of describing the state of research which attempts to preserve the fertility of cancer patients.
\end{abstract}

\author{
Keywords \\ Cancer, Cryopreservation, Oncofertility
}

\section{Introduction}

Cancer is can be manifested almost anywhere in the body, this pathology is characterized by the abnormal growth and division of the cell, due to a failure of the control system from the cell cycle, which can result in tumor formation [1]. Each year, thousands of investigations are conducted around the world with the aim of finding a cure for cancer, but oncologic patients' greatest hope is still radio and chemotherapy. These forms of therapy can result in cell's lysis in the human body, whether the cells are malignant or non-cancerous. In this context, germ cells are among the various types of cells that are damaged by the treatment. Consequently, the patient may become infertile due to the treatment [2]. Moreover, the location, size of the tumor, and the intensity of the irradiation applied during the therapy can affect the patient's fertility. Radiotherapy in the lower abdomen can damage or even destroy the ovaries [3]. In chemotherapy, treatment's length of cycles and doses of drugs necessary for disease regression may have a negative effect on ovarian and testicular function [4].

In oncologic patient's offers the oncofertility as a possibility for fertility preservation of the bearer. Through the use of cryopreservation techniques of gametes, 
both female and male, the method is often performed before starting the therapeutic procedure. For men, the most common cryopreservation techniques are the freezing of semen [5] and testicular tissue, which has the purpose of preserving the spermatogonia [6]. On the other hand, the most common cryopreservation technique among women is the freezing of ovarian tissue [7] and oocytes [8]. The cryopreservation of embryos is also a widely used possibility as well [9].

The main goal of cryopreservation is to lower the temperature in order to reduce cell metabolism, giving cells or tissues a long-term preservation. The effectiveness in the results for cryopreservation includes physical and chemical factors that help in the conservation of germ cell viability. In addition, cryoprotectants in cryopreservation, contribute to reduce deleterious effects caused by intracellular ice formation, increasing the survival rate of viable gametes [10].

Considering the importance of the oncofertility and the limited number of studies in this area, the scientific goal of the study is to review and clarify how assisted reproduction biotechniques may help through cryopreservation methods to reestablish future fertility for oncologic patients.

\section{Oncologic Treatment Related to Female Infer- tility}

The number of ovarian follicles decreases throughout the female reproductive lifespan $[11,12]$. The diagnosis of cancer can have a direct effect on the woman's fertility in relation to treatment and radiotherapy. The Anti-Müllerian hormone (AMH) in women with cancer has shown a level inferior, which means a level of fertility below the level considered normal. In addition, about $67 \%$ of breast cancers are hormone positive receptors. Cancer cells have receptors that bind to the hormones estrogen and/or progesterone [5]. Female cancer patients subordinated to chemo and radiotherapy treatments have a lower number of follicular reserves due to the damage of neoplastic treatments at maturation and stimulation of ovarian follicular atresia [13], due to the cytotoxic effects from substances used during the therapy [14]. A major concern is the infertility of young women who get cancer during their fertile years, preventing them from generating children after treatment. These therapeutic methods applied for cancer treatment can cause sexual dysfunction, and consequently infertility [15].

\section{Oncologic Treatment Related to Male Infertility}

Although chemo and radiotherapy are the most commonly used treatments to treat cancer, these techniques might affect male fertility permanently. The incidence of azoospermia in patients after chemo or radiotherapy treatment is a fact to be taken into account
[16]. It is important to clarify that gonadotoxic effects may vary according to the type of chemotherapeutic agent and the doses used [17]. The radiotherapy in man can have negative effects on testosterone production, which plays an essential role in sexual desire, physiology of erection, spermatogenesis and male fertility [18]. In addition, cytotoxic chemotherapy and radiotherapy can lead to testicular failure and may directly affect spermatogenesis. Although many studies about new forms of therapy are still being researched in the oncofertility area, no type of treatment has been found after the chemo and radiotherapy that promotes the synthesis of spermatozoa. Thus, cryopreservation of gametes prior to initiation of treatment is still the best way to maintain male fertility [19].

\section{Cryopreservation}

Cryopreservation is an important adjunct to oncofertility and has been prominent in human reproductive medicine, providing hope for men and women to be able to have biological children at the end of cancer treatment [5]. Cryopreservation involves the conservation of cells and tissues at cryogenic temperatures, usually achieved by storing biological material at ultra-low temperatures using liquid nitrogen at $\left(-196^{\circ} \mathrm{C}\right)$ or its vapor phase $\left(-150^{\circ} \mathrm{C}\right)[20]$. Therefore, the aim of cryopreservation is to preserve cell viability by decreasing cell metabolism, as a consequence of low temperatures maintained for an indefinite period, or when desired, since the material can be thawed to resume normal progress [21].

There are two possible methods of cryopreservation widely used: Slow freezing, considered as conventional, and Vitrification [22]. Vitrification, also known as "ultrafast-freezing", is an cryopreservation technique in which specific substances called cryoprotectants are added in high concentrations in order to minimize the formation of intracellular ice crystals [23]. Cryoprotectant combinations containing two or more substances have been used for vitrification, once many studies have reported a increase in cryosurvival rate [24-26]. In this method, cells are submerged in liquid nitrogen, requiring no longer than 10 minutes to complete the vitrification procedure. This technique is not time-consuming and does not demand expensive tools [27]. Vitrification has been widely used due to its high survival rate and minimum deleterious effects in cells. On the other hand, in slow freezing, also known as the conventional or standard method, the cell is subjected to dehydration, using cryoprotectants in smaller concentration. In slow freezing, the cell's temperature is reduced gradually. This method requires expensive equipment, consisting in a programmable freezing machine [28].

The cryopreservation common process requires five steps:

1. Cell exposure to the cryoprotectant agent: in this 
step, water and cryoprotectant enter equilibrium between the intra and extracellular spaces [29];

2. Cooling and freezing: in the conventional slow method, cooling and freezing occurs. In the Vitrification method only the phenomenon of cooling occurs [20];

3. Storage: this stage is performed using liquid nitrogen $\left(-196^{\circ} \mathrm{C}\right)[30]$;

4. Warming procedure: This procedure happens in a very short time. The sample is taken out from the liquid nitrogen and placed immediately in a warm environment, with the goal of avoiding the formation of additional ice crystals. The temperature of thawing will depend on the type of cell and its characteristic used [31];

5. Removal of the cryoprotective agent: at this stage the cell is rehydrated, withdrawing the cryoprotectant and replacing water, for this stage one or more washes are required, lasting from five to fifteen minutes each in a decreasing cryoprotectant concentration [32].

Through comparing cryopreservation techniques, it is possible to affirm that the main slow freezing technique target is to maintain the balance between osmotic and toxic damages through manipulation of small amounts of cryoprotectants and regulate the formation of ice crystals by freezing the extracellular medium and dehydration of the cells. In contrast the vitrification technique restricts the formation of ice crystals. However, cryoprotectants high concentrations contribute to osmotic and toxic damages [33]. According to a study carried out by Morishima and collaborators in 2017 [34], the vitrification technique is chosen preferentially over the slow freezing, once randomized procedures results approach superior survival rates when this technique is practiced. Nevertheless, literature is still controversial over which technique is the most efficient. There are a few aspects that should be considered in order to choose the best method, such as carefully analying the cell and tissue characteristics to be cryopreserved and the laboratory attributions where the cryopreservation will be performed.

\section{Cryoprotectants}

Intracellular cryoprotectants agents (CPA) are substances that exhibit low molecular weight, characterized to have the ability to enter the cell [35], acting as a substitute for water in the intracellular space [36], and reducing the concentration of concentrations of intracellular electrolytes [30]. However, the efficacy of this substance may be subject to alteration according to the morphological and functional cell characteristics or tissue to be preserved [37]; concentration and type of cryoprotectant, as well as the time of exposure prior to the cryopreservation method. Currently, the most commonly used cryoprotectants substances for cryopreservation are ethylene glycol, propanediol and dimethylsulfoxide, due to their higher competence in cell penetration and lower toxicity compared to glycerol [30]. Non-penetrating extracellular cryoprotectants act through an osmolality amplification process of extracellular space, responsible for taking the water from the cell to the extracellular space, thus preventing the production of ice crystals in the inner space during freezing. These agents may exhibit molecular weight variation. In addition, they may be helpful to the protection and cell membrane stabilization [38]. The most used extracellular cryoprotectants are: sucrose, trehalose, polyvinylpyrrolidone and polyvinyl alcohol.

\section{Oocyte Cryopreservation}

Oocyte cryopreservation technique prolongs the reproductive autonomy in women [39]. This method is highly recommended for cancer patients, usually younger women without partners, and women whose prefer not accept gametes from anonymous donors [40]. In the first stage, the ovaries are stimulated through the application of hormones in a period of three to five weeks before the beginning of the antineoplastic treatment, exogenous gonadotrophins are used in order to guarantee a greater number of oocytes. Thereafter, primary and secondary oocytes are collected and cryopreserved [41]. However, primary oocytes are subjected to in vitro maturation (IVM) process, allowing the cultivation of cumulus-oocyte complexes (COC) that will complement oocyte factors to elicit the response of cumulus cells to meiosis-stimulating elements such as endothelial growth factors (VEGF), follicle stimulating hormone (FSH) and cyclic adenosine Monophosphate (cAMP) modulators [42,43]. This methodology had been studied and applied by several teams around the world, resulting in successful studies on women oocyte cryopreservation $[8,34,44,45]$.

\section{Ovarian Tissue Cryopreservation}

Ovarian tissue cryopreservation (OTC) is auspicious as it can be applied in the case of minors who have not yet reached puberty and do not have oocytes that are suitable for cryopreservation [41]. OTC is considered as one method that aims to preserve the fertility of cancer patients [46]. However, OTC is not a standard method in clinics world [47-49], because still requires a research protocol optimal to be performed [50,51].

OTC is performed in two steps. The first step is to surgically remove the ovarian tissue and then process the ovarian fragment with a tissue slicer [52]. Thus, once the cancer treatment is finished, the tissue can be reintroduced into the pelvic surface. This procedure is known as orthotopic transfer when it happens in the upper part of the other ovary, near the fallopian tubes, or heterotopic implantation when it occurs in different locations, such as the abdominal wall [41]. As a result 
from OTC, Donnez, et al. [53] reported the first birth after autologous human ovarian tissue transplantation. To date, cryopreserved tissue transplantation has already led to more than 130 live births [49,54].

Although ovarian tissue reimplantation has been a major method for oncofertility, it is not suitable for all patients because there may be a risk of reintroduction of malignant cells into cancer-free patients. In this perspective, numerous studies focused on the isolation and in vitro culture (IVC) of preantral follicles from the tissue, before or after cryopreservation, with the aim of removing the contaminating cells from the tissue. In the IVC the preantral follicles growing in vitro until complete maturation. This technique, recently called artificial ovary can, in the future, regain a significant percentage of oocytes capable of being fertilized [55].

In the context of oncofertility, the artificial ovary is intended to enable women with cancer to have children after chemotherapy and/or radiotherapy without the risk of reimplantation of malignant cells $[55,56]$. To improve the results of IVC, several teams worldwide are working to improve follicular isolation techniques, both in humans [56] and non-human primates [57]. In addition to follicular isolation, other steps are essential for the success of the IVC, such as follicle culture system, which can be two-dimensional or three-dimensional. In three-dimensional culture, alginate has been commonly used, demonstrating a positive effect in several studies with preantral follicles of murine, bovine and human [58-61]. Transplantation studies using this substance demonstrated a positive and promising action of fibrin on the follicular survival and integration of the transplanted follicle with host ovarian tissue, both in murine and in humans [62,63]. Furthermore, human preantral follicles isolated and cultured encapsulated in the combination of the fibrin matrix, fibrinogen and trobine were well developed and maintained the viability [64].

The most promising results from the IVC of preantral follicles were the birth of live animals from the murine primordial follicular culture. Despite this result, several researches need to be performed to improve the success of this technique in the various species of mammals [6567].

\section{Semen Cryopreservation}

The efficacy and safety of the utilization of cryopreserved semen through assisted reproduction biotechniques is well established, thus obtaining pregnancy rates, gestational and perinatal outcomes similar to non-cryopreserved semen [68]. The sperm banks (also called cryobank) main focus is to provide high quality spermatozoa for use in reproduction techniques, with several indications: erectile dysfunction; patients with spermatogenesis inhibition due to reproductive age and bearers with any type of cancer, cancer patients that may be subordinated to radio or chemotherapy, or surgeries that may affect fertility potential, such as cryopreservation of semen for men who are about to be submitted to a vasectomy, with the aim of preserving the future fertility [69]. A study performed by Schuffnera and collaborators in 2004 [5] verified two cases of successful gestation after the semen was cryopreserved, prior to the oncological treatment. Subsequently, Zhang and collaborators in 2017 [45] made two attempts in one study. In the first study, an intracytoplasmic sperm injection (ICSI) was proposed for a couple. Twenty-five cumulus-oocyte complexes (CCO) from a 27-year-old woman were transvaginally retrieved under ultrasonography. Twenty-three oocytes were identified in metaphase II. However, around ten inactive sperm were found in her husband's semen, which suffered from severe oligospermia (insufficient secretion of sperm), and even after a testicular biopsy, not one sperm was found. As a result, the couple opted to select half of the oocytes to be fertilized and to have the twelve secondary oocytes cryopreserved for future use. Thus, eleven oocytes were sent to ICSI, however, embryo production and transfer did not result in gestation. In a second trial, the twelve cryopreserved oocytes were thawed and inseminated using cryopreserved semen from another donor in order to perform a new ICSI. After ICSI, the embryos were evaluated, cryopreserved and transferred. The transfer embryos derived from vitrification resulted in the birth of two healthy female babies.

\section{Testicular Tissue Cryopreservation}

Regarding to testicular tissue cryopreservation, the selection of the most appropriate freezing procedure should be considered, once the spermatogonia, Sertoli and Leydig cells contain a fragile cytoplasm from the freezing and thawing process. These cells have a large projection of water in their inner space, which favors the increase of crystal ice formation which can cause the organelles destruction, through exaggerated cellular dehydration, affected by the osmotic shock after the formation of crystals and rupture of the cytoskeleton after exposure to low temperatures [70]. As a result, a research carried out by $[71,72]$ has been performed with the aim of improving protocols in order to preserve the viability of the testicular tissue after cryopreservation. Researchers reported two studies performing a cryopreserved tissues evaluation after xenograft. In the first study, three weeks after xenotransplantation in mice, they observed a good survival rate and proliferation of spermatogonial and Sertoli cells after cryopreservation of the male's testicular tissue before puberty using a modified protocol previously developed by [73]. In the second study, after 6 months (compared to 3 weeks in the previous study), the grafted tissue was retrieved for evaluation. A qualitative ultrastructural evaluation did not reveal any type of damage in spermatogonia, after freezing and grafting, and Sertoli and Leydig cells 
were described as normal. Immunostaining showed a significant decrease in the number of tubular spermatogonial cells in cryopreserved grafted tissues when compared to fresh tissue. However, immunostaining for Ki-67 and MAGE-A4 (cell proliferation markers) revealed that more than one-third of the spermatogonial cells in the cryopreserved grafted tissue preserved the ability to proliferate even after 6 months. Therefore, the two studies performed by $[71,72]$ show that although the population of human spermatogonia occurs, these cells are able to survive and proliferate, even after cryopreservation and grafting. it is worth noting that while survival rate of cancer patients is increasing, safeguard oncofertility, especially for young patients is still particularly challenging. Although (ICSI) [74] the use of frozen spermatozoa has revolutionized the treatment of infertility, it is not appropriate for patients subordinated to chemotherapy before puberty, since spermatogenesis has not yet been leveraged. Thus, cryopreservation of spermatogonial stem cells located in testicular tissue may be an alternative for these prepubertal patients with risk of damage or loss of their sperm development, due to cancer treatments and developmental or genetic disorders [6]. In this context, some studies reveal that successful autotransplantation and birth in mice [75] and primates [76], after using this technique, shows a very promising future for cell therapy based on these procedures.

\section{Embryo Cryopreservation}

Trounson and Mohr [77] reported the first living birth derived from embryo cryopreservation biotechnology, the study was renowned in the medical literature and considered as revolutionary. Consequently, this achievement brought the possibility for oncologists to forward patients for cryopreservation of embryos prior to the oncological treatment. However, funding and access to cryopreservation has been the major barrier worldwide [78]. On the other hand, among the innumerable advantages that this biotechnology can provide, the best benefit is to provide cancer patients some hope and safety about their future fertility before cancer treatment [79]. Embryo freezing is considered as an alternative to preserve the embryos obtained from in vitro fertilization. This technique is generally used after transfer of embryos since there are remaining viable embryos. Thus, if in vitro fertilization is not successful, the embryo is protected for later cycles [80] (this is $s$ long sentence, please break it into two). In addition to enhancing the possibility of obtaining a successful treatment, the embryo cryopreservation method and economic costs, and allows a new attempt without the need for a new hormonal stimulation [81].

Despite their high resistance to cryoinjury, the criteria that human embryos must meet to be selected for cryopreservation are quite strict. Embryo classification varies in a scale from 1 to 4 , in which only grades 1 and 2 embryos are considered suitable for cryopreservation (I don't think this is universally true. I believe many clinics freeze Grade 2 embryos), since these present symmetries in their embryonic mass and blastomers, with absence of cytoplasmic fragmentation. Using this protocol, the best results are obtained by freezing embryos at the stage of 4 to 8 cells [80]. Cryopreservation of embryos holds numerous reproductive success rates and is widely disseminated throughout the world. The success rates vary according to the patient's age, oocyte characteristics, time of implantation of the thawed embryos; ovarian reserve and treatment success (number of oocytes obtained and fertilized) according to $[9,40,42,45,82]$.

\section{Conclusions and Perspectives}

Based on the above considerations, it is possible to understand the techniques that allow for the preservation of a cancer patient's fertility (oncofertility) before radiotherapy and chemotherapy. As discussed throughout this study, there are several methods for the conservation of reproductive autonomy, both male and female, for example through cryopreservation of germ cells and fragments of ovarian and testicular tissues. Therefore, performing these procedures provides a perspective to allow these patients to have children after the end of treatment.

In summary, the knowledge of professionals of the area, directed to techniques of assisted reproduction is necessary. These specialists should be able to dialogue and clarify doubts about cancer, as this pathology entails substantial damage, including reproductive ones.

\section{Competing Interests}

The authors declare that they have no competing interests.

\section{References}

1. Stratton MR (2011) Exploring the genomes of cancer cells: Progress and promise. Science 331: 1553-1558.

2. Harmer V (2011) Breast Cancer Nursing Care and Management. Blackwell Publishing, 1-384.

3. Larsen EC, Schmiegelow K, Rechnitzer C, Loft A, Müller J, et al. (2004) Radiotherapy at a young age reduces uterine volume of childhood cancer survivors. Acta Obstet Gynecol Scand 83: 96-102.

4. Littley MD, Shalet SM, Morgenstern GR, Deakin DP (1991) Endocrine and reproductive dysfunction following fractionated total body irradiation in adults. Q J Med 78: 265-274.

5. Schuffnera A, Ramosc L, Stocklera S, Hernandesa R, Costaa S, et al. (2004) Criopreservação de gametas: uma esperança para pacientes com câncer. Rev Bras Cancerol 50: $117-120$

6. Zarandi NP, Galdon G, Kogan S, Atala A, Sadri-ardekani H (2018) Cryostorage of immature and mature human testis tissue to preserve spermatogonial stem cells (SSCs): A systematic review of current experiences toward clinical 
applications. Stem Cells Cloning 11: 23-38.

7. Jadoul $P$, Guilmain A, Squifflet J, Luyckx M, Votino R, et al. (2017) Efficacy of ovarian tissue cryopreservation for fertility preservation: Lessons learned from 545 cases. Hum Reprod 32: 1046-1054.

8. Seshadri S, Saab W, Exeter H, Drew E, Petrie A, et al. (2018) Clinical outcomes of a vitrified donor oocyte programme: A single UK centre experience. Eur J Obstet Gynecol Reprod Biol 225: 136-140.

9. Ozgur K, Bulut H, Berkkanoglu M, Humaidan P, Coetzee K (2018) Artificial cryopreserved embryo transfer cycle success depends on blastocyst developmental rate and progesterone timing. Reprod Biomed Online 36: 269-276.

10. Alves KA, Alves BG, Beletti ME, Lúcio AC, Jacomini JO (2013) Criopreservação de folículos pré-antrais caninos com glicerol e etilenoglicol. Arch Vet Sci 18: 8-13.

11. Hansen KR, Knowlton NS, Thyer AC, Charleston JS, Soules MR, et al. (2008) A new model of reproductive aging: The decline in ovarian nongrowing follicle number from birth to menopause. Hum Reprod 23: 699-708.

12. Wood JW (1989) Fecundity and natural fertility in humans. Oxf Rev Reprod Biol 11: 61-109.

13. Falcone T, Bedaiwy MA (2005) Fertility preservation and pregnancy outcome after malignancy. Curr Opin Obstet Gynecol 17: 21-26.

14. Lopes SPF (2010) Preservação da Fertilidade em Doentes Oncológicos. Acta Obstet Ginecol Port, 2-28.

15. Schover LR (2005) Sexuality and fertility after cancer. Hematology Am Soc Hematol Educ Program, 523-527.

16. Meseguer M, Molina N, García-Velasco JA, Remohí $\mathrm{J}$, Pellicer A, et al. (2006) Sperm cryopreservation in oncological patients: A 14-year follow-up study. Fertil Steril 85: $640-645$.

17. Meirow D, Nugent D (2001) The effects of radiotherapy and chemotherapy on female reproduction. Hum Reprod Update 7: 535-543.

18. Carvalho VA, Franco MHP, Kovacs MJ, Liberato RP, Macieira RC, et al. (2008) Temas em psico-oncologia. SP Summus 6: 97-98.

19. Pasqualotto FF (2007) Investigation and assisted reproduction in the treatment of male infertility. Rev Bras Ginecol Obstet 29: 103-112.

20. Santos IRI (2000) Criopreservação: Potencial e perpectivas para a conservação de germoplasma vegetal. Rev Bras Fisio Veg 12: 70-84.

21. Rubinsky B (2003) Principles of low temperature cell preservation. Heart Fail Rev 8: 277-284.

22. Belascoain MG, Díaz ET, Hüter S (2010) Técnicas para la criopreservación de embriones bovinos. U Nacion de Cór 2-19.

23. Vajta G (2000) Vitrification of the oocytes and embryos of domestic animals. Anim Reprod Sci 60: 357-364.

24. Squires EL, Keith SL, Graham JK (2004) Evaluation of alternative cryoprotectants for preserving stallion spermatozoa. Theriogenology 62: 1056-1065.

25. Álvarez C, Gil L, González N, Olaciregui M, Luño V (2014) Equine sperm post-thaw evaluation after the addition of different cryoprotectants added to INRA 96 extender. Cryobiology 69: 144-148.

26. Wu Z, Zheng X, Luo Y, Huo F, Dong H, et al. (2015)
Cryopreservation of stallion spermatozoa using different cryoprotectants and combinations of cryoprotectants. Anim Reprod Sci 163: 75-81.

27. Cho SK, Cho SG, Bae IH, Park CS, Kong IK (2002) Improvement in post-thaw viability of in vitro-produces bovine blastocysts vitrified by glass micropipette. Anim Reprod Sci 73: 151-158.

28. Edgar DH, Gook DA (2012) A critical appraisal of cryopreservation (slow cooling versus vitrification) of human oocytes and embryos. Hum Reprod Update 18: 536-554.

29. Gunasena KT, Villines PM, Critser ES, Critser JK (1997) Live births after autologous transplant of cryopreserved mouse ovaries. Hum Reprod 12: 101-106.

30. Castro SV, Carvalho AA, Silva CMG, Faustino LR, Figueiredo JR, et al. (2011) Agentes crioprotetores intracelulares: características e utilização na criopreservação de tecido ovariano e oócitos de tecido ovariano e oócitos. Acta Sci Vet 39: 1-18.

31. Fabbri R, Porcu E, Marsella T, Primavera MR, Rochetta G, et al. (2000) Technical aspects of oocyte cryopreservation. Mol Cell Endocrinol 169: 39-42.

32. Newton H, Fisher J, Arnold JRP, Pegg DE, Faddy MJ, et al. (1998) Permeation of human ovarian tissue with cryoprotective agents in preparation for cryopreservation. Hum Reprod 13: 376-380.

33. Vajta G (1997) Vitrification of bovine oocytes and embryos. Embryo Transfer 15: 12-18.

34. Morishima C, Santos TB, Takahira AM, Donadio N, Cavagna M, et al. (2017) Relato de caso: Crianças nascidas após vitrificação de oócitos em reprodução assistida em hospital público. Reprod Climat 32: 148-151.

35. Rall WF, Reid DS, Polge C (1984) Analysis of slow warming injury of mouse embryos by cryomicroscopical and physiochemical methods. Cryobiology 21: 106-121.

36. Jain KJ, Paulson RJ (2006) Oocyte cryopreservation. Fertil Steril 86: 1037-1046.

37. Fuller B, Paynter S (2004) Fundamentals of cryobiology in reproductive medicine. Reprod Biomed Online 9: 680-691.

38. Watson PF (1995) Recent developments and concepts in the preservation of spermatozoa and the assessment of their post-thawing function. Reprod Fertil Dev 7: 871-891.

39. Matos MJ, Torres I, Sousa S, Freitas P, Carvalho D (2012) Preservação da fertilidade na mulher com cancro. Rev Port Endocrinol Diabetes Metabol 7: 44-51.

40. Moraes LG (2010) Preservação da fertilidade em pacientes portadoras de neoplasias malignas. Rev Med Resid 12: 3544.

41. Castellotti DS, Cambiaghi AS (2008) Fertility preservation for oncologic patiens. Rev Bras Hematol Hemoter 30: 406410.

42. Nogueira D, Ron-El R, Friedler S, Schachter M, Raziel A, et al. (2006) Meiotic arrest in-vitro by phosphodiesterase 3-inhibitor enhances maturation capacity of human oocytes and allows subsequent embryonic development. Biol Reprod 74: 177-184.

43. Zeng HT, Richani D, Sutton-McDowall ML, Ren Z, Smitz $\mathrm{JE}$, et al. (2014). Prematuration with cyclic adenosine monophosphate modulators alters cumulus cell and oocyte metabolism and enhances developmental competence of in vitro-matured mouse oocytes. Biol Reprod 91: 47.

44. Cobo A, García-Velasco JA, Coello A, Domingo J, Pellicer 
A, et al. (2016) Oocyte vitrification as an efficient option for elective fertility preservation. Fertil Steril 105: 755-764.

45. Zhang Z, Zhu J, Zhang H, Xi Q, Geng, D, et al. (2017) Live birth after transfer of vitrified-warmed embryo derived from vitrified-warmed oocyte and frozen-thawed sperm following failed ICSI. Rev Med Chil 145: 402-405.

46. Lierman S, Tilleman K, Cornelissen M, De Vos WH, Weyers $S$, et al. (2015) Follicles of various maturation stages react differently to enzymatic isolation: A comparison of different isolation protocols. Reprod Biomed Online 30: 181-190.

47. Stoop D, Cobo A, Silber S (2014) Fertility preservation for age-related fertility decline. Lancet 384: 1311-1319.

48. Donnez J, Dolmans MM (2015) Ovarian cortex transplantation: 60 reported live births brings the success and worldwide expansion of the technique towards routine clinical practice. J Assist Reprod Genet 32: 1167-1170.

49. Donnez J, Dolmans MM (2017) Fertility preservation in women. N Engl J Med 377: 1657-1665.

50. Isachenko E, Isachenko V, Nawroth F, Rahimi G, Weiss JM (2009) Effect of longterm exposure at suprazero temperatures on activity and viability of human ovarian cortex. Fertil Steril 91: 1556-1559.

51. Kamoshita K, Okamoto N, Nakajima M, Haino T, Sugimoto $\mathrm{K}$, et al. (2016) Investigation of in vitro parameters and fertility of mouse ovary after storage at an optimal temperature and duration for transportation. Hum Reprod 31: 774-781.

52. Ferreira FP, Soares Júnior JM, Motta ELA (2011) Preservação da fertilidade: A importância de oferecer esta possibilidade às pacientes com doenças neoplásicas. Rev Bras Ginecol Obstet 33: 223-226.

53. Donnez J, Dolmans MM, Demylle D, Jadoul P, Pirard C et al. (2004) Live birth after orthotopic transplantation of cryopreserved ovarian tissue. Lancet 364: 1405-1410.

54. Ruan X, Du J, Korell M, Kong W, Lu D, et al. (2018) Case report of the first successful cryopreserved ovarian tissue retransplantation in China. Climacteric 31: 1-4.

55. Anderson RA, Wallace WHB, Telfer EE (2017) Ovarian tissue cryopreservation for fertility preservation: Clinical and research perspectives. Hum Reprod Open 1-9.

56. Xiao S, Zhang J, Romero MM, Smith KN, Shea LD, et al. (2015) In vitro follicle growth supports human oocyte meiotic maturation. Sci Rep 5: 17323.

57. Xu J, Lawson MS, Yeoman RR, Pau KY, Barrett SL, et al (2011) Secondary follicle growth and oocyte maturation during encapsulated three-dimensional culture in rhesus monkeys: Effects of gonadotrophins, oxygen and fetuin. Hum Reprod 26: 1061-1072.

58. Xu M, Kreeger PK, Shea LD, Woodruff TK (2006) Tissueengineered follicles produce live, fertile offspring. Tissue Eng 12: 2739-2746.

59. Sadr SZ, Fatehi R, Maroufizadeh S, Amorim CA, Ebrahimi B (2018) Utilizing fibrin-alginate and matrigel-alginate for mouse follicle development in three-dimensional culture systems. Biopreserv Biobank 16: 120-127.

60. McLaughlin M, Telfer EE (2010) Oocyte development in bovine primordial follicles is promoted by activin and FSH within a two-step serum-free culture system. Reproduction 139: 971-978.

61. Yin $H$, Kristensen SG, Jiang $H$, Rasmussen $A$, Andersen CY (2016) Survival and growth of isolated pre-antral follicles from human ovarian medulla tissue during longterm 3D culture. Hum Reprod 31: 1531-1539.

62. Kniazeva E, Hardy AN, Boukaidi SA, Woodruff TK, Jeruss JS, et al. (2015) Primordial follicle transplantation within designer biomaterial grafts produce live births in a mouse infertility model. Sci Rep 5: 17709.

63. Chiti MC, Dolmans MM, Mortiaux L, Zhuge F, Ouni E, et al. (2018) A novel fibrin-based artificial ovary prototype resembling human ovarian tissue in terms of architecture and rigidity. J Assist Reprod Genet 35: 41-48.

64. Paulini F, Vilela JM, Chiti MC, Donnez J, Jadoul P, et al. (2016) Survival and growth of human preantral follicles after cryopreservation of ovarian tissue, follicle isolation and short-term xenografting. Reprod Biomed Online 33: 425-432.

65. Eppig JJ, O'Brien MJ (1996) Development in vitro of mouse oocytes from primordial follicles. Biol Reprod 54: 197-207.

66. O'Brien MJ, Pendola JK, Eppig JJ (2003) A revised protocol for in vitro development of mouse oocytes from primordial follicles dramatically improves their developmental competence. Biol Reprod 68: 1682-1686.

67. Morohaku K, Tanimoto R, Sasaki K, Kawahara-Miki R, Kono T, et al. (2016) Complete in vitro generation of fertile oocytes from mouse primordial germ cells. Proc Natl Acad Sci U S A 113: 9021-9026.

68. Lansac J, Thepot F, Mayaux MJ, Czyglick F, Wack T, et al. (1997) Pregnancy outcome after artificial insemination or IVF with frozen semen donor: A collaborative study of the French CECOS Federation on 21,597 pregnancies. Eur $\mathrm{J}$ Obstet Gynecol Reprod Biol 74: 223-228.

69. Cavalcante MB, Duarte ABG, Araújo DOD, Teles EPDB (2006) Criopreservação de sêmen humano: comparação entre métodos de congelação e tipos de envase. Rev Bras Ginecol Obstet 28: 708-714.

70. Chaveiro A, Liu J, Mullen S, Woelders H, Critser JK (2004) Determination of bull sperm membrane permeability to water and cryoprotectants using a concentration-dependent self-quenching fluorophore. Cryobiology 48: 72-80.

71. Wyns C, Curaba M, Martinez-Madrid B, Van Langendonckt A, François-Xavier W, et al. (2007) Spermatogonial survival after cryopreservation and short-term orthotopic immature human cryptorchid testicular tissue grafting to immunodeficient mice. Hum Reprod 22: 1603-1611.

72. Wyns C, Van Langendonckt A, Wese FX, Donnez J, Curaba M (2008) Long-term spermatogonial survival in cryopreserved and xenografted immature human testicular tissue. Hum Reprod 23: 2402-2414.

73. Keros V, Rosenlund B, Hultenby K, Aghajanova L, Leykov, $\mathrm{L}$, et al. (2005) Optimizing cryopreservation of human testicular tissue: Comparison of protocols with glycerol, propanediol and dimethylsulphoxide as cryoprotectants. Hum Reprod 20: 1676-1687.

74. Oliveira ECS (2015) Criopreservação de tecido testicular. Rev Bras Reprod Anim 39: 109-110.

75. Brinster RL, Avarbock MR (1994) Germline transmission of donor haplotype following spermatogonial transplantation. Proc Natl Acad Sci U S A 91: 11303-11307.

76. Hermann BP, Sukhwani M, Winkler F, Pascarella JN, Peters $\mathrm{KA}$, et al. (2012) Spermatogonial stem cell transplantation into rhesus testes regenerates spermatogenesis producing functional sperm. Cell Stem Cell 11: 715-726.

77. Trounson U, Mohr L (1983) Human pregnancy following 
cryopreservation, thawing and transfer of an eight-cell embryo. Nature 30: 707-709.

78. Barcroft J, Dayoub N, Thong KJ (2013) Fifteen year followup of embryos cryopreserved in cancer patients for fertility preservation. J Assist Reprod Gen 30: 1407-1413.

79. Tschudin S, Bitzer J (2009) Aspectos psicológicos da preservação da fertilidade em homens e mulheres afetados por câncer e outras doenças potencialmente fatais. Hum Reprod Atual 15: 587-597.
80. Santin TR, Blume H, Mondadori RG (2009) Criopreservação de embriões: Metodologias de vitrificação. Vet e Zootec 16: 561-574.

81. Gasda EE (2015) Criopreservação de embriões humanos no contexto da saúde sexual e reprodutiva. Rev Pistis praxis $7: 635-661$.

82. Silva F, Pinelo S, Pires I, Felgueira E (2015) Preservação da fertilidade feminina: Novos desafios. Acta Obstet Ginecol Port 154-157. 